\title{
留学から始まった人的交流と研究
}

\author{
山口潤一郎
}

\section{Studying Abroad Led to New Friendships and New Research Directions}

\author{
Junichiro Yamaguchi \\ Department of Applied Chemistry, Waseda University; 3-4-1 Okubo, Shinjuku-ku, Tokyo 169-8555, Japan.
}

(Received August 4, 2018)

\begin{abstract}
Ten years ago, in April 2007, I went abroad to study at The Scripps Research Institute (TSRI) in San Diego, USA. As an overseas researcher with the Japan Society for the Promotion of Science (JSPS), I worked with Professor Phil S. Baran (an associate professor at the time), who was a distinguished young researcher in synthetic organic chemistry. Working abroad had been my dream ever since I had decided to work at a university as a researcher. Through my study of organic chemistry, I hoped to spread my wings and explore the world. Fortunately, the research projects at TSRI went well, and a year and a half later, I returned to Japan, to Nagoya University as an assistant professor (under the guidance of Professor Kenichiro Itami). During my time abroad, I certainly gained a lot of experience in chemistry, but as I look back to 10 years ago, I feel that the personal interactions remain much more important to me. Numerous Japanese researchers who studied overseas around the same period, and many TSRI graduate students I encountered, are currently faculty members at top universities around the world. At this memorable and nostalgic phase of my life, I am sharing here a personal account of the research I conducted and the researchers I met during my stay in San Diego.
\end{abstract}

Key words_— studying abroad; postdoctoral researcher; The Scripps Research Institute; Japan Society for the Promotion of Science

筆者が大学教員となって 10 年が経過した. 光陰 矢の如しである。それ以前は米国で博士研究員をし ていた. 本稿では当時の海外留学の経験（研究）と 人的交流が, 10 年後どのように生きているのか, いかに役に立っているのかについて述べる.

\section{自己紹介}

はじめに筆者の自己紹介をしよう。筆者は 1997 年に東京理科大学工業化学科に入学し, 2002 年に 卒業している，賢明な読者の皆様はすぐにわかるで あろうが, 大学卒業に 5 年の月日を費やしている. より端的に述べれば, 留年だ. 1 年生の有機化学の 単位を 3 度落とし留年した. 留年時の 1 年間は化学 を中心に猛勉強し, 誰にも負けないぐらい知識をつ けたつもりだ。その際に現在も継続して代表をして いる国内最大の化学ウェブサイトChem-Station

早稲田大学理工学術院（广169-8555 東京都新宿区大久 保 3-4-1)

e-mail: junyamaguchi@waseda.jp

本総説は, 日本薬学会第 138 年会シンポジウム S02 で

発表した内容を中心に記述したものである.
(略称：ケムステ）を立ち上げた. ${ }^{1)}$ その後, 学部 4 年次より林 雄二郎教授 (現 : 東北大院)に師事し, 2007 年に博士（工学）を得た。その間, 博士課程 後期 2 年次に， 1 力月間という短期間であるが，米 国スクリプス研究所の K. C. Nicolaou 研に留学す る機会を得た。博士取得後は, 日本学術振興会の海 外特別研究員 (海外 PD) として, 同研究所の Phil S. Baran 教授の下で研究を行った. 約 1 年半後の 2008 年夏に名古屋大学大学院理学研究科助教（伊 丹健一郎教授）となり，2012 年に准教授，2016 年 に現所属である早稲田大学理工学術院に研究室責任 者として移勤し， 2018 年 4 月から教授である。さ て，上述したように，米国スクリプス研究所で 2 回 の留学を経験している. 両者あわせても 2 年にも満 たない短期間であるが，得た経験と人間関係は現在 かけがえなのないものとなっている.

\section{留学時の研究}

留学したスクリプス研究所は, 米国カリフォルニ ア州サンディエゴにあり，私立研究所としては世界 でも最大級の規模を誇る。化学分野においても多数 

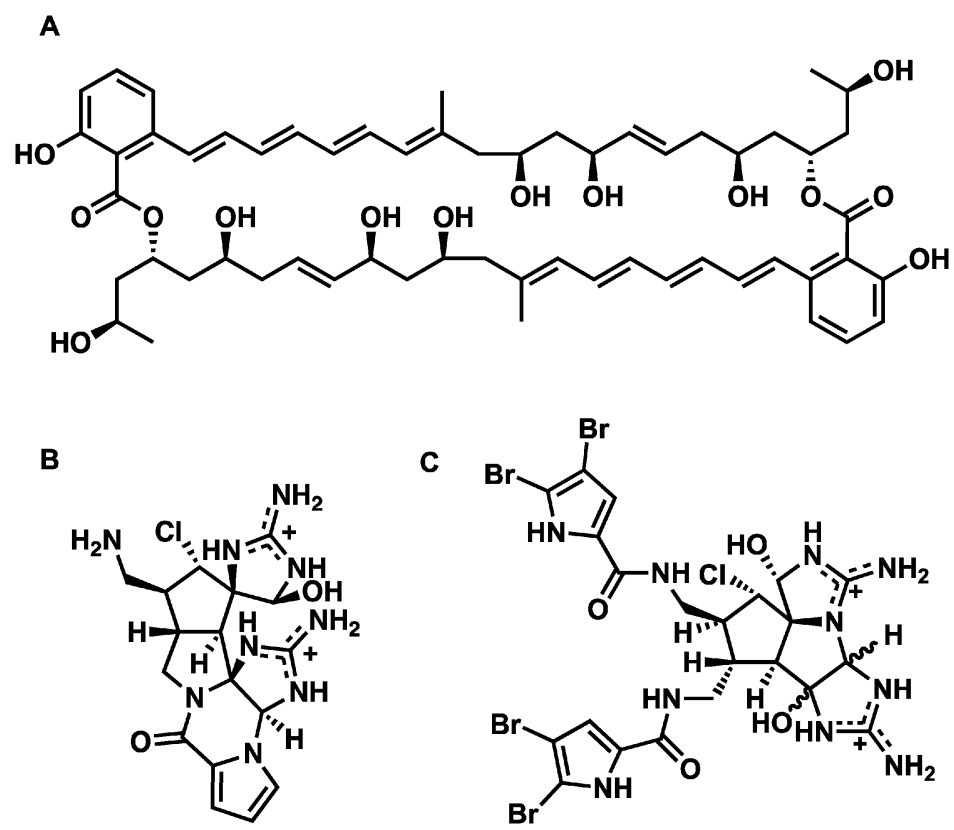

Fig. 1. (A) Marinomycin A, (B) Palau'amine, and (C) Axinellamines A and B

のスーパースター教授と多数の博士研究員・大学院 生が属している。 Nicolaou 教授（現：米国ライス 大学）は天然物合成の第一人者である。留学時 (2005 年 10 月), 筆者がポリエン化合物の合成に長 けていたことからか，当時合成研究が行われていた ポリエンを持つ大環状化合物マリノマイシン類 [marinomycins: Fig. 1(A)］の合成チームに配属さ れた。林教授から，かならず論文に名前を載せても らえるぐらいの活躍をするようにと念を押されてい たため， 1 カ月（実質研究できたのは 3 週間）で 100 実験ほどをこなした。実験はほぼスポーツのよ うであり，1 kg の試薬を使用したり，5L の反応容 器， $5 \mathrm{~L}$ の分液漏斗の利用から始まった。 あまりの 激務であったからか，米国の高カロリーな食事を人 一倍食べていたにもかかわらず，はじめの 1 週間で $4 \mathrm{~kg}$ 瘦せた. 1 力月の滞在期間, 900 ドルでシェア した（実際は 2700 ドル）素敵な家で眠ったのは 3 日間だけでほとんど研究所内で夜を明かした。結局,

17 工程ほどの合成中間体を $10 \mathrm{~g}$ 合成し，なんとか 論文に名前を載せて頂いた. ${ }^{2}$

2 度目は博士研究員として 2007 年 4 月に渡米し た。ライジングスターであった Baran 教授（当時 准教授）を選んだのは，彼の合成に常識でないなに かを感じたことと，年齢も 1 歳しかかわらない「天 才」と時を共有したかったからだ。与えられたテー

マはパラウアミン［(palau'amine: Fig. 1(B)］の合 成研究であった。当時多くの研究室が挑戦して合成 できず敗れ去った，難攻不落・前人未到の超複雑天 然物だ。テーマを与えられた際には，もう少し簡単 な?テーマも同時並行したいという気持ちであった が，当時そんな英語を話すことはできず「Yes!」と 答えるのが精一杯であった。 3 力月全く研究がうま くいかない日々が続き，議論もうまくできず辛かっ たが，自分で考案した合成ルートがうまくいき始 め，急激に周囲から注目され始めた，運よく，類縁 体であるアキシネルアミン A と B [axinellamines A and B: Fig. 1(C) ] を研究開始から約 9 力月で合 成でき（実験ノートに記載したものだけで 1000 実 験ほど行った），論文を 2 報投稿したところで少し 安心を得た. ${ }^{3,4)}$ (かにも簡単に合成できたように述 ベたが，ほとんど研究所内に住み着いているぐらい 研究に没頭した結果である。このスタイルは体力的 な陰りは大いに感じるが，いまでもあまりかわって

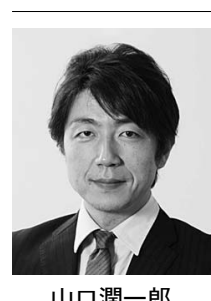

山口潤一郎
2007 年東京理科大学大学院博士課程修 了. 博士 (工学)。米国スクリプス研究 所博士研究員を経て，2008 年名古屋大 学理学研究科助教となる。 2012 年同大 学院准教授となり, 2016 年早稲田准教 授 (研究室主宰)，2018 年より教授. 専門は有機合成化学. 
A.

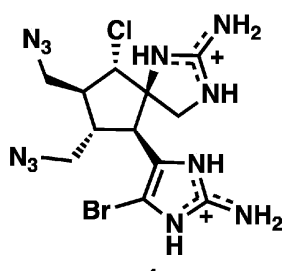

1

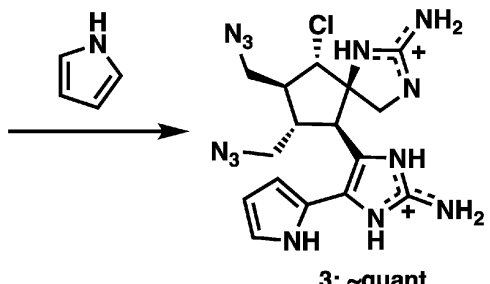

3: quant

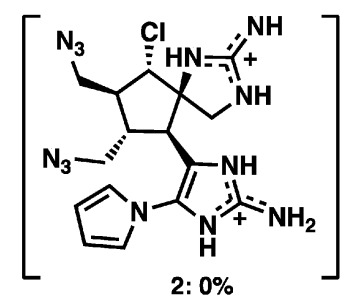

2: $0 \%$

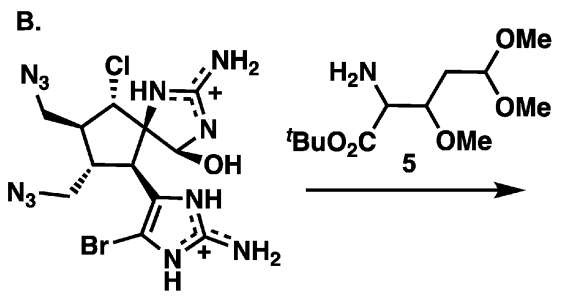

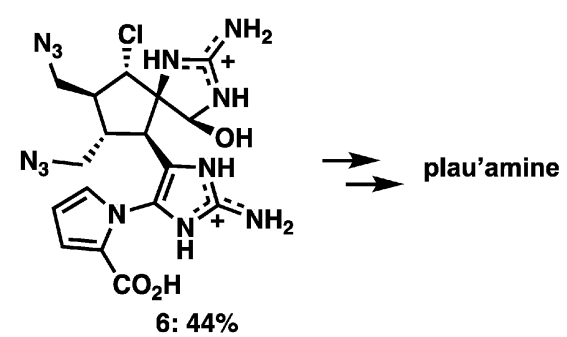

Fig. 2. (A) C-H Arylation of Pyrrole, and (B) Coupling of Pyrrole Units

いない．おかげで同様に深夜から朝方まで研究して いる他の研究室の仲間とも知り合うことができた. 一方で個人的な話になるが，留学時に結婚をした妻 が 2 月後半から渡米し, 同居し始めたので, 7 月途 中の帰国までは 100 実験ほどしかやらず，次のポジ ションでの研究を考えていた。研究人生で最もリ ラックスした期間だった。 なお，通常研究者として 注目されている限り，いままさにそのときよりも楽 になることは二度とないと思ったほうがよいだろう。

帰国 1 力月ほど前から，パラウアミンの合成研究 において，ブロモ体 $\mathbf{1}$ にピロールのカップリング反 応を検討していたときのことである，遷移金属触媒 を用いた Buchwald-Hartwig 型のカップリング反応 を考えていたが，触媒や塩基を入れるとそれだけで 原料が消失し，全くうまくいかなかった，それなら ば，なにも入れずに熱してやれということで，原料 とピロールのみを熱してみたところ，目的の化合物 2 は得られなかったが，定量的にピロールの C2 位 で反応が進行した化合物 $\mathbf{3}$ が得られた。同僚にはそ んな反応がうまくいくわけないと嘲笑されたが, やってみるものである．原料のアミノイミダゾール 環の芳香族性の低さが原因で，ピロールの芳香族求 電子置換反応が進行したためであるが，この結果が 官能基を用いず直接へテロ芳香環を “アリール化” する C-H アリール化反応の複雑天然物合成への応 用のアイデアへつながった。帰国 2 日前の出来事で あった. なお, 肝心のパラウアミン合成は, 後にピ ロールに変換可能なより求核性の高いアミンを用い
て反応を行うことを共同研究者に託した．共同研究 者は，Fig. 2 のようなピロール等価体 4 を用いて窒 素原子選択的に反応を進行させ $\mathbf{5}$ を $\mathbf{6}$ とし，数段階 を経た後に, 前人未到天然物の全合成を達成し た. 5,6$)$

\section{留学後の研究}

帰国後名古屋大学で始めた研究は上述した通り, 留学時の経験により着想を得た C-H アリール化反 応を駆使した複雑天然物合成だ。正確に言えば，骨 格をつくり直接酸化段階をあげて（C-H 酸化反応） 多官能基化された天然物をつくるというプロジェク トも行っていたが，学部生と自分だけのチームでは 世界の有力研究室には全く歯が立たず，1-2 年で同 じコンセプトの論文が出始めたので撤退した．所属 していた伊丹研究室ではチオフェンの C-H アリー ル化反応が開発されていたので，それをべースとし て反応開発から始めた。ほとんど遷移金属触媒を 使ったことがなかったので，苦労したが，学生たち の努力のおかげで，ユニークなへテロ芳香環の C-H カップリング反応とそれを促進する独自の触 媒を開発することができた. ${ }^{7)}$ 現職の早稲田大学に 移勤してからはこの化学研究は行っていないが, 有 機金属化学を勉強しながら既存の天然物合成と組み 合わせ，新しい化学を立ち上げることができて満足 している.

\section{留学から始まった「人脈」}

研究もさることながら，筆者が一番得たものは留 学で得た「人脈」である。上述したようにスクリプ 
ス研究所はトップクラスの研究所であり, 博士研究 員も大学院生も超優秀な場合が多い. 場合が多いと 述べたのは，当たり前だがすべてではないことだ. しかし類は友を呼ぶという諺通り，䆃命に化学に打 ち込んでいると自然にそのような「友」があつまる. 逆も然りであるため気をつけてほしい. 日本人研究 者にも留学先として人気があり，アカデミックポジ ションを希望する研究者から，主に製薬企業を中心 であるが，1-2 年の出向で博士研究員として働いて いる研究者も多数所属していた．主にアカデミアに いる研究者を中心に述べるが，Nicolaou 研究室の ときには，石川勇人氏（現・熊本大教授）に大変お 世話になった．化学に熱く，このようなひとに会え るのならばもういちど博士研究員としてこの研究所 に戻りたいと思ったきっかけとなった人だ。帰国 後，石川氏を林教授に紹介し筆者の博士取得後，入 れ替わりで林研究室の助教となった。ほかにも山㠃 龍氏（現・昭和薬大准教授），岩澤哲郎氏（現・龍 谷大教授）・野村 渉氏（現・東京医科歯科大准教 授）にも仲よくして頂いた.

2 度目の留学では，より多くの人と出会った。鈴 木孝洋氏（現・北大准教授）・鈴木孝禎氏（現・京 都府立医大教授），滝澤 忍氏（現・大阪大准教 授），浦 康之氏（現・奈良女子大准教授），梅澤大 樹氏（現・北大准教授），小野田 晃氏（現・大阪大 准教授），北垣伸治氏（現・名城大教授），重久浩樹 氏（現・武蔵野大講師）などだ.

鈴木孝禎氏とは，その後 C-H アリール化を用い た HDAC 阻害剂と LSD1 阻害剤の構造薬理活性相 関で共同研究を行った. ${ }^{8-11)}$ スクリプス出身，そし て同じアパートメントで同じ時を過ごした（筆者は ほとんどいなかったが）同僚であるからこそ，研究 は円滑に進んだ。

日本のスクリプス研究所出身者は，日本スクリプ 又会という出身者の同空会を有しており，東西に分 かれて年に 1 回シンポジウムと懇親会を行ってい る. ${ }^{12)}$ そこでその後の留学者との交流も可能であ る. 名古屋時代の学生も数人訪問学生としてまた博 士研究員として留学している. かくいう今回のシン ポジウム主催者の小松 徹・伊藤幸裕両氏もスクリ プス研究所出身の後輩だ。現所属である早稲田大に おいても，同僚である中田雅久教授と細川誠二郎准 教授もスクリプス研究所での博士研究員経験者であ
り，このコミュニティーの大きさを実感できるとと もに，化学の世界の狭さを感じることができる.

もちろん，この人脈は日本人研究者に限ってのこ とでない，特に大学院生は大変優秀であり，多くの 当時の大学院生が米国・その他で主要なポジション を得ている. 当時の仲のよかつた大学院生を述べる と, Baran 研究室出身からは Ryan Shenvi（スクリ プス研究所)・Tom Meimone (UCバークレイ校), Noah Burns (スタンフォード大)，Tim Newhouse (イェール大)， Ian Seiple（UC サンフランシスコ 校), Hans Renata（スクリプス研究所）がいた. また Nicolaou 研究室は David Sarlah（イリノイ大 学アーバナシャンペーン校), Ang Li (上海有機化 学研究所)，そして Yu 研究室からは Masayuki Wasa（ボストン・カレッジ）である。ちなみに本 稿の Summary の英文校閲をお願いしたのも Baran 研時代の学生である石原義大氏だ（現・Vertex Pharmaceuticals)。彼はカナダ人であり，英語はも ちろんのこと化学も抜群にできるため, 英文校閲を 頼むとしたら彼に依頼することに決めている.

昨年歴史があるへテロ環化合物のゴードン会議に 招待された。 日本からの招待講演者は筆者のみだ. 筆者のような若輩者が招待されるのもおこがましい が，日本のある先生が推薦してくれたこと，また主 催者であった Daniel Romo 教授（ベーラー大）が palau'amine の合成研究に携わっており，筆者のこ とを知ってくれていたことが理由だ．留学先の経験 がこんなところでつながりがでてくるとは思わな かった。なお，上述した David Sarlah と Tim Newhouse の二人にも本会議で久々に会い，ゴードン会 議の連日の飲み会を楽しんだ。ボストンを訪問した ついでに Masayuki Wasa のいるボストン・カレッ ジも訪問した.

もちろん，日本に訪問する際はいの一番に連絡を くれる. Ryan Shenvi と Masayuki Wasa の講演会 を本学（早稲田大）で主催した。今年の夏も Noah Burns と David Sarlah が訪日し, 講演を行ってく れるので楽しみである。さらに，今年の冬には David Sarlah の呼びかけで, 米国の 8 大学の講演旅 行に招待された。訪問するのはほとんどがスクリプ ス研究所の元同僚であり，感謝としか言いようがな い. 


\section{最後に}

留学は研究のヒントを与え，友とのつながりをく れたかけがえのない経験である。なお具体性を持た せるために，当事者以外にはあまり身にならない個 人的なことを連々と記載したことに関してはご容赦 頂きたい.

\section{利益相反＼cjkstart開示すべき利益相反はない.}

\section{REFERENCES}

1) Chem-Station: 〈https://www.chem-station. com $\rangle$, cited 8 January, 2019.

2) Nicolaou K. C., Nold A. L., Milburn R. R., Schindler C. S., Cole K. P., Yamaguchi J., J. Am. Chem. Soc., 129, 1760-1768 (2007).

3) Yamaguchi J., Seiple I. B., Young I. S., O'Malley D. P., Maue M., Baran P. S., $A n$ gew. Chem., Int. Ed., 47, 3578-3580 (2008) .

4) O’Malley D. P., Yamaguchi J., Young I. S., Seiple I. B., Baran P. S., Angew. Chem. Int., Ed., 47, 3581-3583 (2008).

5) Seiple I. B., Su S., Young I. S., Lewis C. A., Yamaguchi J., Baran P. S., Angew. Chem., Int. Ed., 49, 1095-1098 (2010).
6) Seiple I. B., Su S., Young I. S., Nakamura A., Yamaguchi J., Jørgensen L., Rodriguez R. A., O’Malley D. P., Gaich T., Köck M., Baran P. S., J. Am. Chem. Soc., 133, 14710-14726 (2011).

7) Yamaguchi J., Itami K., Bull. Chem. Soc. Jpn., 90, 367-383 (2017) .

8) Sekizawa H., Amaike K., Itoh Y., Suzuki T., Itami K., Yamaguchi J., ACS. Med. Chem. Lett., 582-586 (2014).

9) Miyamura S., Araki M., Suzuki T., Yamaguchi J., Itami K., Angew. Chem., Int. Ed., 54, 846-851 (2015).

10) Miyamura S., Araki M., Ota Y., Itoh Y., Yasuda S., Masuda M., Taniguchi T., Sowa Y., Sakai T., Suzuki T., Itami K., Yamaguchi J., Org. Biomol. Chem., 14, 8576-8585 (2016).

11) Ota Y., Miyamura S., Araki M., Itoh Y., Yasuda S., Masuda M., Taniguchi T., Sowa Y., Sakai T., Itami K., Yamaguchi J., Suzuki T., Bioorg. Med. Chem., 26, 775-785 (2018).

12) The Japan Scripps Society: 〈https://japanscripps.chem-station.com $\rangle$, cited 8 January, 2019. 